\title{
Mer nyansert oppfølging ved celleforandringer
}

\author{
Analyse av vevsmarkører kan skille celleforandringer på livmorhalsen \\ som vil gå tilbake spontant fra celleforandringer som må behandles.
}

Celleforandringer på livmorhalsen (cervikal intraepitelial neoplasi, CIN) skyldes infeksjon med ulike typer humant papillomvirus (HPV). HPV 16 og 18 er de virustypene som er sterkest assosiert med invasiv livmorhalskreft.

- Celleforandringer på livmorhalsen kan utvikle seg videre til livmorhalskreft. Årlig blir 3000 kvinner i Norge operert på grunn av CIN stadium 2 eller 3. Operasjonen kan svekke livmorhalsen og gi økt risiko for senabort eller for tidlig fødsel ved eventuell graviditet, sier Ane Cecilie Dæhli Munk.

- Mange kvinner blir unødvendig behandlet, siden vi ikke har sikre metoder som kan skille mellom celleforandringer som går spontant tilbake og forandringer som vil utvikle seg videre til kreft. Inntil $50 \%$ av celleforandringene kan gå tilbake av seg selv uten behandling fordi immunsystemet bekjemper viruset. Men hvis det ikke gis behandling, vil $31 \%$ av tilfellene av CIN stadium 3 utvikle seg til invasiv kreft, sier hun.
Munk har undersøkt om analyse av virustype og ulike vevsmarkører sammen med kliniske faktorer kan skille ut pasienter med høy sannsynlighet for spontan tilbakegang. Fire måneders oppfølging av kvinner med CIN2-3 viste at analyse av retinoblastomprotein, størrelse på lesjon og CD4 i stroma kan brukes til å skille mellom dem med høy $(53 \%)$ og dem lav (6\%) sannsynlighet for spontan tilbakegang (regresjon). Ved kondombruk økte regresjonsraten til $67 \%$. Hos kvinner som var HPV16-negative, men positive for andre høyrisikogenotyper, økte regresjonsraten til $73 \%$ ved kondombruk.

- En vente-og-se-tilnærming med jevnlige kontroller og bruk av kondom ved samleie kan være fordeaktig for unge kvinner med høy sannsynlighet for tilbakegang, sier hun.

\section{Anne Forus}

anneforus@hotmail.com

Tidsskriftet

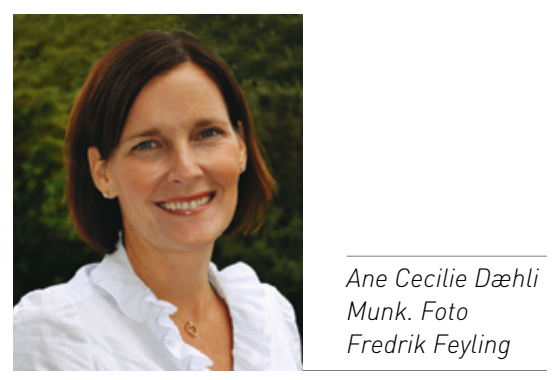

Disputas

Ane Cecilie Dæhli Munk disputerte for ph.d-graden ved Universitetet i Bergen 9.11. 2012. Tittel på avhandlingen er Molecular biomarkers, human papillomavirus-genotypes and clinical factors in regression prediction of cervical intraepithelial neoplasia grades 2-3.

\section{Avisers «genprofil» er kartlagt}

\author{
Hva slags forståelse av begrepet «gen» får vi når vi leser ulike aviser?
}

I sin avhandling har Rebecca Bruu Carver funnet at genbegrepet kan vinkles på fem ulike måter, og at det er tydelig forskjell på hvordan tabloidaviser og kvalitetsaviser behandler begrepet.

- Kunnskap om gener er viktig fordi de står sentralt i en rekker temaer - alt fra mat, helse og sykdom til prøverørsbarn og kriminalpolitikk. Men det er ufattelig vanskelig å definere hva et gen er, sier Carver.

Gjennom en kvalitativ innholdsanalyse av 300 norske og britiske avisartikler fant Carver at gener kan være fysiske ting inne i cellene, f.eks. «Genene settes med sprøyte», direkte årsaker til egenskaper, f.eks. «Genet som gjør deg tjukk», risikofaktorer for sykdommer, f.eks. «Genet øker sjansen for å få kreft», dynamiske faktorer, f.eks. «Både gener og miljø er viktig», eller humoristiske symboler brukt i overført betydning, f.eks. «Saab med Ford-gener».

Deretter undersøkte hun forekomsten av de fem genrammene i 12 internasjonale aviser med ulike typer lesere (600 artikler) og fant at tabloidavisene, som har lesere med lavere utdanningsnivå, bruker genbegrepet først og fremst som et humoristisk symbol. De mer seriøse avisene, der leserne har et høyere utdanningsnivå, foretrekker de mer vitenskapelige rammene. Konklusjonen er derfor at folk i ulike sosiale lag får ulikt inntrykk av hva gener er.

- Dette kan være uheldig for mennesker som bare leser tabloidaviser, fordi de sjelden får den innsikten de trenger for å forstå temaer knyttet til genetikk, avslutter Carver.

Carver og hennes medarbeidere har brukt resultatene til å lage et opplegg for genetikkundervisningen i den videregående skolen. Studien tyder på at en bevisstgjøring rundt de fem ulike genrammene kan hjelpe elever til å bli mer kritiske avislesere, noe som også kan utvide deres forståelsesramme når det gjelder gener.

\section{Tone Bergset}

tone.bergset@legeforeningen.no

Tidsskriftet

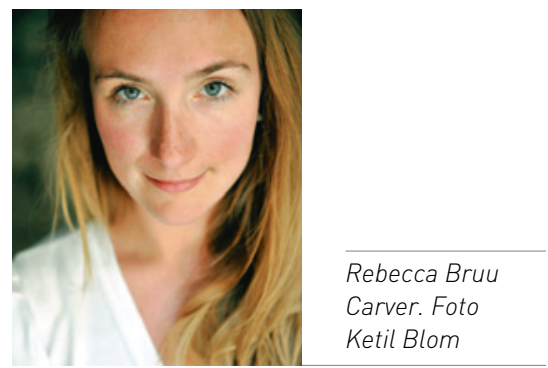

Disputas

Rebecca Bruu Carver disputerte for ph.d.graden ved Universitetet i Oslo 1.3. 2013 Tittelen på avhandlingen er Framing the gene: a science communication study of how newspapers frame different meanings of the gene concept, with applications for science education. 